\title{
Faktor Perilaku dan Gaya Hidup yang Mempengaruhi Status Prediabetes Pasien Puskesmas Pati II
}

\author{
Ninik Trisnawati Sukenty ${ }^{*}$, Zahroh Shaluhiyah ${ }^{*}$, Antono Suryoputro*) \\ ${ }^{*}$ Magister Program Promosi Kesehatan Fakultas Kesehatan Masyarakat Universitas Diponegoro \\ Korespondensi: kens_moed@yahoo.com
}

\begin{abstract}
Background: Prediabetes status describes as the condition of blood glucose level above normal but insufficient to be diagnosed as diabetes. The stage of prediabetes is a critical condition of blood glucose level, but could reverse to be normal again if healthy lifestyle is routinely performed. In USA one of three people diagnosed with prediabetes. But most people did not realize that they had prediabetes history. The increasing number of prediabetes occurs due to the absence of typical symptoms. If prediabetes detected earlier, the rate of diabetes mellitus could be prevented. This study aims to examine some behaviors that affect the prediabetes status of patients in Pati II health center.
\end{abstract}

Method: This is an explanatory research with cross sectional approach. Samples were rucruited using inclusion criteria such as aged 40-59 years, not diagnosed as diabetes, abdominal circumference more than 90 for men and 80 for women. There were 117 respondents involved in this study.

Results: This research showed that the number of respondents with prediabetes status was 39.3\%. Respondents with blood glucose level ranged more than $200 \mathrm{mg} / \mathrm{dl}$ were $6 \%$. The variables that influence the prediabetes status of the respondents were Body Mass Index with OR 3.591 ( $p$ value 0.011), diet pattern with OR 2.435 ( $p$ value 0.044), and smoking habit or passive smoking with OR 2.493 ( $p$ value 0.046). This study recommends to prevent the prediabetes to be diabetes, needed the socialization of healthy lifestyle to the community and early detection of prediabetes. Early prevention includes changes to people healthy lifestyles such as maintaining healthy body weight, doing physical activity routinely, healthy eating patterns, avoiding cigarette smoke and smoking habits.

Keywords: prediabetes, BMI, diet, smoking

\section{PENDAHULUAN}

Dari angka statistik, sekitar 3,2 juta jiwa per tahun penduduk yang meninggal akibat diabetes melitus. ${ }^{(1)}$ Diabetes melitus disebut juga The Great Imitator karena penyakit ini dapat mengenai semua organ tubuh dan menimbulkan berbagai macam keluhan, kecacatan dan kematian. ${ }^{(1)}$ Riset Kesehatan Dasar (Riskesdas) 2013 menunjukkan data prevalensi diabetes di Indonesia terdiagnosis dokter sebesar $1,5 \%$ naik menjadi 2 kali lipat dari Riskesdas 2007. ${ }^{(2)}$ Sedangkan Jawa Tengah memiliki prevalensi diabetes melitus melebihi angka nasional yaitu sebesar $1,6 \%$. $^{(2)}$ Penemuan kasus baru diabetes mellitus Provinsi Jawa Tengah tahun 2014 mencapai 121.203 orang, dan Kabupaten Pati termasuk dalam peringkat kelima tertinggi penyumbang angka kasus baru tersebut. ${ }^{(2)(3)}$ Selain termasuk dalam 3 besar penyakit tidak menular, di Kabupaten Pati prevalensi 
diabetes melitus mengalami kenaikan yang signifikan dalam 5 tahun terakhir, dimana angka tertinggi terjadi di wilayah kerja Puskesmas Pati II. ${ }^{(3)}$

Sebelum diabetes mellitus terjadi, maka didahului terjadinya prediabetes, yaitu keadaan kadar gula darah tidak cukup tinggi untuk dikategorikan sebagai diabetes mellitus tetapi sudah mendekati angka borderline. ${ }^{(4)}$ Hal ini dapat menjadi dasar upaya pencegahan diabetes mellitus, yaitu dengan mengontrol dan mengelola prediabetes agar dapat menjadi normal kembali dan tidak menuju kearah diabetes. ${ }^{(4)}$

Prevalensi prediabetes seperti fenomena gunung es, jumlahnya ditemukan lebih banyak daripada kasus diabetes mellitus. Banyaknya angka kejadian prediabetes yang tidak terdeteksi dikarenakan kasus prediabetes tidak menimbulkan gejala khas seperti diabetes mellitus. ${ }^{(5)}$ Termasuk di Indonesia, prevalensi prediabetes diperkirakan sekitar 300 juta orang. ${ }^{(5)}$

Adapun faktor yang mempengaruhi prediabetes telah diketahui dari penelitianpenelitian sebelumnya, seperti: usia, kegemukan, riwayat diabetes keluarga, pola makan, aktivitas fisik, dan merokok. $^{(5)(6)(7)}$ Penelitian mengenai prediabetes telah dilakukan diberbagai negara seperti Australia, Amerika Serikat, Inggris, Finlandia, Cina, dan Arab Saudi.
Sedangkan di Indonesia masih terbatas, terutama di Jawa Tengah.

\section{METODE}

Jenis penelitian ini adalah penelitian explanatory dengan rancangan studi cross sectional. Populasi penelitian adalah penduduk usia 40-59 tahun berjumlah 13.419 jiwa. ${ }^{(3)}$ Sampel dipilih pada penduduk yang memenuhi persyaratan inklusi dan ekslusi sampel. Terlebih dahulu menghitung jumlah minimal sampel, yaitu 100 responden. Kriteria inklusi sampel adalah: berumur 40-59 tahun, belum pernah terdiagnosa diabetes melitus, memiliki keluarga (keluarga kandung dan atau keluarga satu nenek) dengan riwayat diabetes melitus, memiliki lingkar perut $>90 \mathrm{~cm}$ (untuk pria) dan $>80 \mathrm{~cm}$ (untuk wanita), dalam kondisi mandiri (dapat berdiri sendiri tanpa bantuan alat atau siapa pun), mampu menjawab pertanyaan, dan bersedia mengikuti proses penelitian dengan menandatangani informed consent. Kriteria eksklusi adalah: terdiagnosis diabetes melitus saat pemeriksaan dilakukan, tidak bersedia mengikuti proses pemeriksaan sampai selesai. Pemilihan anggota sampel dilakukan dengan cara Simple Random Sampling, dimana jumlah minimal sampel dibagi proporsi sesuai jumlah populasi ke dalam 12 desa binaan dan masing masing desa ditambahkan 4 orang untuk 
menanggulangi bila terdapat calon responden yang terdiagnosa diabetes maupun responden yang tidak ingin melanjutkan proses penelitian. Kegiatan skrining dilakukan mulai akhir bulan Juni sampai dengan Agustus 2016. Total sampel awal adalah 148 orang, namun terdapat 22 orang yang terdiagnosa diabetes, dan 9 orang tidak melanjutkan proses pemeriksaan sehingga dihasilkan sampel akhir adalah 117 orang.

Cara pengambilan data responden penelitian menggunakan 2 cara, yaitu: pengisian kuesioner dan pengukuran anthropometri, gejala klinis serta pengukuran gula darah kapiler. Pengambilan darah dilakukan 3 kali, yaitu GDS (Gula Darah Sewaktu); GDP (Gula Darah Puasa), dan GD2PP (Gula Darah 2 jam Post Pandrial).

Variabel bebas dalam penelitian ini adalah umur, jenis kelamin, Index Massa Tubuh, tingkat pendidikan, pekerjaan, pendapatan keluarga, pola makan, aktivitas fisik, dan merokok. Untuk kemudian dianalisa dengan variabel terikat yaitu status prediabetes. Analisa data menggunakan 2 uji statistik, yaitu bivariat untuk menganalisa hubungan masingmasing variabel bebas dengan terikat dengan menggunakan uji Chi-Square, dan dilanjutkan multivariat dengan menggunakan uji statistik Multiple Logistic Regression.

\section{HASIL DAN PEMBAHASAN}

Angka Kejadian Prediabetes di Puskesmas Pati II

Penentuan prediabetes telah ditetapkan oleh Pengendalian Penyakit dan Penyehatan Lingkungan Kemenkes RI. ${ }^{(8)}$ Status prediabetes didiagnosa oleh dokter berdasarkan anamneses gejala klinis serta hasil laboratorium kadar gula darah minimal 3 kali pemeriksaan. Hasil pemeriksaan tersebut yang menentukan status prediabetes. Status prediabetes terdiri dari Gula Darah Puasa Terganggu (GDPT), Toleransi Gula Terganggu (TGT), maupun gabungan antara TGT dan GDPT. Prediabetes yang termasuk dalam kelompok GDPT apabila pasien tidak merasa mengalami gejala klinis diabetes, dan ditegakkan dengan bukti pemeriksaan kadar gula darah dalam 3 kali permeriksaan, GDS (Gula Darah Sewaktu) 140-199mg/dl, kemudian pemeriksaan kedua GDP (Gula Darah Puasa) menunjukkan angka 100-125mg/dl, dan pada pemeriksaan terakhir melalui TTGT (Test Toleransi Gula Terganggu) yang hasil pemeriksaannya disebut GD2PP (Gula Darah 2 jam Post Pandrial) menunjukkan gula darah kurang dari 140mg/dl. ${ }^{(9)}$ Prediabetes yang termasuk dalam TGT adalah responden yang merasa mengalami gejala klinis diabetes, namun pada periksaan GDS tidak melebihi dari 200mg/dl, GDP menunjukkan kurang dari 
$126 \mathrm{mg} / \mathrm{dl}$, dan GD2PP menunjukkan nilai 140-199mg/dl. ${ }^{(9)}$ TGT juga dapat terdeteksi pada responden yang tidak merasa mengalami gejala klinis, namun GDS menunjukkan lebih dari $200 \mathrm{mg} / \mathrm{dl}$, dan nilai GD2PP berada pada nilai 140199mg/dl. ${ }^{(9)}$ Prediabetes juga bisa terdeteksi dari gabungan TGT dan GDPT, baik dengankeluhan klinis maupun tidak ada keluhan klinis, dan untuk memastikannya dapat dilihat dari nilai GDS 140-199mg/dl, nilai GDP 100$125 \mathrm{mg} / \mathrm{dl}$, dan nilai GD2PP berkisar pada 140-199mg/dl. Tabel 1 menunjukkan hasil distribusi status prediabetes berdasarkan pemeriksaan gula darah.

Tabel 1. Distribusi Rincian Status Gula Darah Responden

\begin{tabular}{lcc}
\hline $\begin{array}{c}\text { Status } \\
\text { Prediabetes }\end{array}$ & Frekuensi & $\begin{array}{c}\text { Prosentase } \\
(\%)\end{array}$ \\
\hline Normal & 71 & 60,7 \\
TGT & 12 & 10,3 \\
GDPT & 27 & 23,1 \\
GDPT + TGT & 7 & 6,0 \\
\hline Jumlah & 117 & 100,0 \\
\hline
\end{tabular}

Dari prosentase status gula darah tersebut dapat diperlihatkan jumlah keselurahan prediabetes pada responden. Prosentase TGT 10,3\% penelitian ini hampir menunjukkan prosentase yang sama dengan penelitian Pradana Soewondo \& Laurentius A. Pramono tahun 2011. ${ }^{(5)}$

Berdasarkan hasil di tabel 2 menunjukkan bahwa angka kejadian prediabetes tergolong tinggi dibandingkan dengan Hasil Riset Kesehatan Dasar (Riskesdas) tahun 2007 yang menunjukkan bahwa prevalensi prediabetes hampir dua kali lipat dari prevalensi Diabetes Melitus tipe 2 yaitu 10,2\%. ${ }^{(2)}$ Beberapa tahun kemudian pada penelitian Balitbangkes tahun 2013 prosentase beranjak menjadi 13,1\%. ${ }^{(2)}$ Angka kejadian prediabetes $39,3 \%$ pada penelitian ini telah diprediksi mengalami peningkatan dari tahun sebelumnya, mengingat situasi sekarang semakin banyak resiko pemicunya.

Tabel 2. Distribusi Frekuensi Status Prediabetes Responden

\begin{tabular}{lrc}
\hline $\begin{array}{c}\text { Status } \\
\text { Prediabetes }\end{array}$ & Frekuensi & $\begin{array}{c}\text { Prosentase } \\
(\%)\end{array}$ \\
\hline Prediabetes & 46 & 39,3 \\
Normal & 71 & 60,7 \\
\hline Jumlah & 117 & 100,0 \\
\hline
\end{tabular}

\section{Karakteristik Demografi}

Hasil penelitian menunjukkan bahwa sebagian besar responden memiliki umur 45-59 tahun sebesar 72,6 \%, sedangkan responden kelompok dewasa dini yaitu umur kurang dari 45 tahun sebesar $27,4 \%$.

Berdasarkan uji tabulasi silang menunjukkan bahwa responden dengan status prediabetes lebih banyak terdapat pada kelompok dewasa madya (berumur antara 45-59 tahun) yaitu sebesar 43,5\% jika dibandingkan dengan responden dewasa dini (berumur kurang dari 45 tahun) sebesar 28,1\%, begitupun 
sebaliknya. Dalam penelitian Shara Trisnawati dan Setyorogo umur merupakan salah satu faktor resiko kejadian diabetes. ${ }^{(10)}$ Meskipun demikian, hasil analisis uji Chi-Square diperoleh nilai pvalue $0,191 \quad(p>0,05)$ yang berarti tidak ada hubungan signifikan antara umur dengan status prediabetes pada responden. Keadaan tersebut dapat disebabkan karena perbedaan umur yang tidak jauh antara kelompok responden yang berumur kurang dari 45 tahun (dewasa dini) dan kelompok umur 45-59 tahun (dewasa madya). Hal ini juga terjadi pada penelitian Lina Aulia Ulfa dimana variabel umur tidak berhubungan dengan kadar gula darah. ${ }^{(11)}$

Pada variabel jenis kelamin sebagian besar responden berjenis kelamin perempuan. Hasil uji tabulasi silang menunjukkan bahwa status prediabetes cenderung lebih banyak terdapat pada kelompok responden laki-laki $(48,4 \%)$ dibandingkan responden yang berjenis kelamin perempuan $(36,0 \%)$. Hasil uji Chi Square diperoleh pvalue 0,321 (pvalue $>0,05$ ), artinya tidak ada hubungan yang signifikan antara jenis kelamin dengan status prediabetes responden di wilayah kerja Puskesmas Pati II. Hal ini sejalan penelitian Nezhad yang memperlihatkan tidak adanya hubungan yang bermakna antara variabel jenis kelamin dan kejadian penigkatan kadar gula darah. $^{(12)}$
IMT merupakan salah satu cara penentuan obesitas pada tubuh seseorang. Obesitas atau kegemukan terjadi apabila hasil perhitungan IMT lebih dari 25. ${ }^{(8)}$ Dari penelitian ini didapatkan 2 dari 3 responden mengalami kegemukan. Obesitas menggambarkan kumpulan lemak berlebih pada individu, yang dapat menyebabkan resistensi insulin. Kondisi ini disebabkan oleh menurunnya kemampuan hormon insulin untuk menurunkan kadar glukosa darah. ${ }^{(8)}$

Normalnya, glukosa darah akan disimpan di sel otot, sel hati, ataupun sel lemak sebagai sumber energi. Namun karena terjadinya resistensi insulin, glukosa tidak dapat memasuki sel sehingga kadar glukosa darah cenderung meningkat tapi belum menyebabkan diabetes secara klinis. ${ }^{(8)}$ Keadaan ini lama-kelamaan akan menyebabkan pankreas kelelahan sehingga tidak mampu mengeluarkan insulin sesuai kebutuhan. Kondisi yang demikian menyebabkan gula di hati dihasilkan berlebih dan tidak terkendali sehingga kadar gula dalam darah meningkat, dan mencapai pada tahap prediabetes. ${ }^{(8)}$

Responden yang berstatus prediabetes didominasi responden yang memiliki IMT lebih (47,4\%). Sedangkan responden yang memiliki kadar gula darah normal lebih banyak memiliki IMT yang normal (76,9\%). Uji hubungan Chi Square menghasilkan nilai pvalue 0,019 yaitu 
terdapat hubungan yang signifikan antara IMT dengan kadar gula darah responden.. Hasil ini sesuai studi Pradana Soewondo dan Laurentius A. Pramono dari hasil analisis data Riskesdas 2007 menyimpulkan bahwa obesitas berhubungan dan mempengaruhi prediabetes (pvalue 0,0001). ${ }^{(5)}$

Sebagian besar responden berpendidikan rendah, yaitu tidak sekolah, tidak tamat, dan tamat SD. Responden prediabetes lebih banyak terdapat pada responden yang berpendidikan rendah sebesar 40,0\% dibandingkan dengan responden yang berpendidikan tinggi yaitu sebesar 38,1\%. Hasil uji Chi Square menghasilkan p-value sebesar 0,996 (pvalue $>0,05$ ), berarti tidak ada hubungan yang bermakna antara tingkat pendidikan dengan status prediabetes responden. Hal ini sejalan dengan penelitian Duke yang memperlihatkan pendidikan tidak berhubungan dengan peningkatan kontrol glikemik seseorang. ${ }^{(13)}$

Responden yang tidak bekerja (ibu rumah tangga, pensiunan dan pengangguran) lebih banyak dibandingkan kelompok bekerja. Pada uji Chi-Square menghasilkan nilai $p$-value sebesar 0,688 (pvalue $>0,05$ ), artinya tidak ada hubungan antara status pekerjaan dengan status prediabetes responden. Penelitian yang sejalan adalah penelitian Abidah Nur dan rekan tahun yang menganalisis penelitian
Riset Pembinaan Kesehatan tahun 2014, yaitu tidak ditemukan hubungan signifikan antara status pekerjaan dengan kadar gula darah. ${ }^{(14)}$

Pendapatan keluarga responden didominasi oleh responden dengan pendapatan keluarga rendah (kurang dari UMR Kabupaten Pati), namun tidak terpaut jauh dengan kelompok penghasilan tinggi. Hasil uji Chi Square diperoleh $p$ value 0,792 (pvalue $>0,05$ ), artinya tidak ada hubungan antara pendapatan keluarga dengan status prediabetes. Hal ini sejalan dengan penelitian Nadia Kholila tahun 2015 yang menyatakan bahwa pendapatan keluarga tidak berpengaruh langsung terhadap kadar gula darah seseorang. ${ }^{(15)}$

\section{Perilaku dan Gaya Hidup Responden} (Pola Makan, Aktivitas Fisik, dan

\section{Kebiasaan Merokok)}

Pola makan dalam penelitian ini menitikberatkan pada asupan kalori total yang menjadi salah satu indikator pola makan yang tidak terkontrol dan mengakibatkan kadar glukosa darah meningkat, sehingga berkontribusi terjadinya prediabetes. $^{(15)}$ Adapun metabolisme yang mempengaruhi kadar gula darah adalah asupan kalori yang diubah menjadi energi. Gula darah atau gula yang beredar di dalam aliran darah berfungsi sebagai penyedia energi bagi tubuh dan seluruh sel-sel jaringan tubuh. ${ }^{(15)}$ 
Ketika kadar gula dalam darah tinggi, maka sel beta pulau langerhans pada pankreas akan mengeluarkan insulin. Insulin tersebut akan menurunkan kadar gula dalam darah dengan cara mendistribusikan gula masuk ke dalam selsel yang akan diproduksi untuk menghasilkan energi. ${ }^{(17)}$ Namun apabila asupan kalori terus menerus tinggi akan menyebabkan insulin bekerja terlalu berat dan terjadi penurunan fungsi insulin yang berlanjut menjadi prediabetes. ${ }^{(17)}$

Berdasarkan hal tersebut, maka penelitian ini menggunakan indikator total asupan kalori untuk menggambarkan pola makan responden. Perhitungan persen AKG asupan kalori 117 responden melalui wawancara Food Recall 2x 24 jam, menghasilkan data asupan kalori aktual perhari. Nilai persen $\mathrm{AKG}$ asupan kalori responden didapatkan dengan membandingkan asupan kalori aktual perhari dengan asupan kalori tabel AKG anjuran yang telah ditetapkan pada Permenkes RI nomor 75 Tahun 2013. ${ }^{(16)}$ Hasil perhitungan memperlihatkan dominasi responden yang kelebihan asupan kalori (persen AKG >119\%) atau dapat diartikan sebagai pola makan tidak sehat yaitu sebanyak 56,4\%. Hasil uji Chi Square menghasilkan pvalue sebesar 0,034 (pvalue $<0,05$ ), yang artinya ada hubungan yang bermakna antara pola makan dengan status prediabetes responden. Hal ini juga dibuktikan oleh Dian Fibriana tahun $2005 .^{(17)}$

Aktivitas fisik atau disebut juga aktivitas eksternal adalah kegiatan yang menggunakan tenaga atau energi untuk melakukan berbagai kegiatan fisik, seperti berjalan, berlari, berolahraga, dan lain-lain. Setiap kegiatan fisik yang menentukan jumlah energi dikeluarkan menurut lamanya intensitas dan sifat kerja otot. ${ }^{(18)}$ Pengaruh aktivitas fisik secara langsung berhubungan dengan peningkatan kecepatan pemulihan glukosa otot (seberapa banyak otot menyerap glukosa dari aliran darah). ${ }^{(18)}$ Saat beraktivitas fisik, otot menggunakan glukosa yang tersimpan dalam otot dan jika glukosa berkurang, otot mengisi kekosongan dengan mengambil glukosa dari darah. ${ }^{(19)}$ Hal tersebut membuat glukosa darah menurun dan mampu mempertahankan glukosa darah tetap normal. Karena itu, prediabetes dapat dihindarkan bagi orang yang beraktivitas cukup. ${ }^{(19)}$

Pengukuran aktivitas fisik dilakukan dengan menghitung kalori yang dikeluarkan perhari berdasarkan aktivitas fisik yang biasa dilakukan sehari-hari dengan menggunakan rumus Physical Activity Level (PAL). Nilai PAL didapatkan dari hasil pembagian 24 jumlah perkalian antara lama aktivitas fisik yang dilakukan dengan nilai Physical Activity Ratio (PAR) sesuai acuan WHO. ${ }^{(19)}$ Hasil 
aktivitas fisik memperlihatkan prosentase yang hampir sama antara jumlah responden yang aktivitas fisiknya cukup (49,6\%) dengan responden yang aktivitas fisik kurang (50,4\%). Hasil uji hubungan menghasilkan nilai pvalue 0,045, artinya aktivitas fisik berhubungan dengan prediabetes. Hal ini dibuktikan oleh Fajrinayanti dan Dian Ayubi tahun 2008 di Padang Panjang orang dengan aktifitas fisik kurang dari 120 menit/hari memiliki resiko terkena prediabetes. ${ }^{(20)}$

Merokok merupakan kegiatan memasukkan berbagai senyawa kimia berbahaya termasuk berbagai senyawa radikal ke dalam tubuh, baik perokok aktif maupun pasif. Ma et al juga menyatakan bahwa seorang perokok mengalami paparan radikal bebas yang besar dan memiliki kandungan antioksidan plasma yang lebih rendah dibandingkan dengan orang yang tidak merokok. ${ }^{(21)}$ Hal ini berakibat terjadinya kerusakan membrane sel yang berakibat fatal pada metabolisme. Kerusakan metabolisme ini sebagai pencetus resistensi insulin, yang apabila tidak dikontrol dengan baik akan berlanjut pada tahap prediabetes. ${ }^{(21)}$

Penelitian ini memperlihatkan bahwa jumlah responden perokok $(54,7 \%)$ lebih banyak dibandingkan jumlah responden bukan perokok (45,3\%). Persentase kelompok perokok tergolong sangat tinggi mengingat responden banyak yang merupakan ibu rumah tangga. Hal ini disebabkan karena klasifikasi responden perokok tidak hanya bagi responden yang melakukan kegiatan merokok saja, namun termasuk didalamnya responden yang merasa terpapar asap rokok setiap hari yang disebut sebagai perokok pasif. ${ }^{(22)} \mathrm{Uji}$ hubungan Chi Square, memperlihatkan adanya hubungan antara status merokok dengan status prediabetes (pvalue: 0,016). Hubungan signikan ini juga dibuktikan oleh Pramono dengan pvalue: $0,0001 .^{(5)}$

Tabel 3. Distribusi Frekuensi Variabel

\begin{tabular}{lccc}
\hline \multicolumn{1}{c}{ Variabel } & $\mathrm{n}$ & $\%$ & $\begin{array}{c}\text { Normality } \\
\text { Test }\end{array}$ \\
\hline Status Prediabetes & & & \\
Normal & 71 & 60,7 & 0,000 \\
Prediabetes & 46 & 39,3 & 0,000 \\
Umur & & & \\
Dewasa dini (<45 tahun) & 32 & 27,4 & 0,000 \\
Dewasa madya (45-59 tahun) & 85 & 72,6 & 0,000 \\
Jenis Kelamin & & & \\
Laki-laki & 31 & 26,5 & 0,000 \\
Perempuan & 86 & 73,5 & 0,000 \\
\hline
\end{tabular}




\section{IMT}

Normal $(\leq 25,0)$

$39 \quad 33,3 \quad 0,000$

Kegemukan $(>25,0)$

$78 \quad 66,7 \quad 0,000$

Pendidikan

Penddikan Tinggi (Minimal SMA)

$42 \quad 35,9 \quad 0,000$

Pendidikan Rendah (Maksimal SMP)

$75 \quad 64,1 \quad 0,000$

Status Pekerjaan

Bekerja (wiraswasta, petani/buruh/ nelayan, pegawai)

Tidak bekerja (Ibu Rumah Tangga, pensiunan, pengangguran)

\section{Pendapatan Keluarga}

Pendapatan Keluarga Tinggi ( $\geq$ UMR)

Pendapatan Keluarga Rendah (<UMR)

\section{Pola Makan}

Sehat (Persen AKG $\leq 119 \%$ )

$52 \quad 44,4 \quad 0,000$

Tidak sehat (Persen AKG >119\%)

\section{Aktivitas Fisik}

Cukup

$65 \quad 55,6 \quad 0,000$

Kurang

$\begin{array}{lll}58 & 49,6 & 0,000 \\ 59 & 50,4 & 0,000\end{array}$

\section{Kebiasaan Merokok}

Bukan perokok

$51 \quad 43,6 \quad 0,000$

$66 \quad 56,4 \quad 0,000$

Perokok

$58 \quad 49,6 \quad 0,000$

$59 \quad 50,4 \quad 0,000$

Tabel 4. Uji Hubungan antara karakteristik responden, pola makan, aktifitas fisik dan perilaku merokok dengan status prediabetesnya

\begin{tabular}{|c|c|c|c|c|c|c|c|}
\hline \multirow{3}{*}{ Variabel } & \multicolumn{4}{|c|}{ Status Prediabetes } & \multirow{2}{*}{\multicolumn{2}{|c|}{ Total }} & \multirow{3}{*}{$\begin{array}{c}p- \\
\text { Value }\end{array}$} \\
\hline & \multicolumn{2}{|c|}{ Normal } & \multicolumn{2}{|c|}{ Prediabetes } & & & \\
\hline & $\mathbf{n}$ & $\%$ & $\mathbf{n}$ & $\%$ & $\mathbf{n}$ & $\%$ & \\
\hline \multicolumn{8}{|l|}{ Umur } \\
\hline Dewasa dini ( $<45$ tahun $)$ & 23 & 71,9 & 9 & 28,1 & 32 & 100 & 0,191 \\
\hline Dewasa madya (45-59 tahun) & 48 & 56,5 & 37 & 43,5 & 85 & 100 & \\
\hline \multicolumn{8}{|l|}{ Jenis Kelamin } \\
\hline Laki-laki & 16 & 51,6 & 15 & 48,4 & 31 & 100 & 0,321 \\
\hline Perempuan & 55 & 64,0 & 31 & 36,0 & 86 & 100 & \\
\hline \multicolumn{8}{|l|}{ IMT } \\
\hline Normal $(<25,0)$ & 30 & 76,9 & 9 & 23,1 & 39 & 100 & $\mathbf{0 , 0 1 9}$ \\
\hline Kegemukan $(>25,0)$ & 41 & 52,6 & 37 & 47,4 & 78 & 100 & \\
\hline \multicolumn{8}{|l|}{ Tingkat Pendidikan } \\
\hline Pendidikan tinggi (Minimal SMA) & 26 & 61,9 & 16 & 38,1 & 42 & 100 & 0,996 \\
\hline Pendidikan rendah (Maksimal SMP) & 45 & 60,0 & 30 & 40,0 & 75 & 100 & \\
\hline \multicolumn{8}{|l|}{ Status Pekerjaan } \\
\hline $\begin{array}{l}\text { Bekerja (wiraswasta, petani/buruh/ } \\
\text { nelayan, pegawai) }\end{array}$ & 30 & 57,7 & 22 & 42,3 & 52 & 100 & 0,688 \\
\hline Tidak bekerja (Ibu Rumah Tangga, & 41 & 63,1 & 24 & 36,9 & 65 & 100 & \\
\hline
\end{tabular}




\begin{tabular}{llllllll}
\hline pensiunan, pengangguran) & & & & & & & \\
\hline Pendapatan Keluarga & & & & & & & \\
Pendapatan tinggi (>UMR) & 34 & 58,6 & 24 & 41,4 & 58 & 100 & 0,792 \\
Pendapatan rendah (<UMR) & 37 & 62,7 & 22 & 37,3 & 59 & 100 & \\
\hline Pola Makan & & & & & & & \\
Pola makan sehat (persen AKG $\leq 119 \%)$ & 37 & 72,5 & 14 & 27,5 & 51 & 100 & \\
Pola makan tidak sehat (persen AKG & 34 & 51,5 & 32 & 48,5 & 66 & 100 & $\mathbf{0 , 0 3 4}$ \\
$>119 \%$ ) & & & & & & & \\
\hline Aktivitas Fisik & & & & & & & \\
Aktivitas fisik cukup & 41 & 70,7 & 17 & 29,3 & 58 & 100 & $\mathbf{0 , 0 4 5}$ \\
Aktivitas fisik kurang & 30 & 50,8 & 29 & 49,2 & 59 & 100 & \\
\hline Kebiasaan Merokok & & & & & & & \\
Bukan perokok & 39 & 73,6 & 14 & 26,4 & 53 & 100 & $\mathbf{0 , 0 1 6}$ \\
Perokok & 32 & 50,0 & 32 & 50,0 & 64 & 100 & \\
\hline
\end{tabular}

Tabel 5. Hasil Analisis Multivariat

\begin{tabular}{|c|c|c|c|c|c|c|c|}
\hline \multirow{2}{*}{ Variabel } & \multirow{2}{*}{ B } & \multirow{2}{*}{ SE } & \multirow{2}{*}{ Wald } & \multirow{2}{*}{ Sig. } & \multirow{2}{*}{$\begin{array}{c}\operatorname{Exp} \\
\text { (B) }\end{array}$} & \multicolumn{2}{|c|}{ CI 95\% } \\
\hline & & & & & & Lower & Upper \\
\hline Umur & .792 & .543 & 2.129 & .145 & 2.208 & .762 & 6.399 \\
\hline Jenis & -.577 & .517 & 1.245 & .265 & .562 & .204 & 1.548 \\
\hline IMT & 1.279 & .505 & 6.410 & .011 & 3.591 & 1.335 & 9.663 \\
\hline Pola Makan & .890 & .442 & 4.060 & .044 & 2.435 & 1.025 & 5.785 \\
\hline Aktivitas Fisik & .546 & .444 & 1.511 & .219 & 1.726 & .723 & 4.119 \\
\hline Merokok & .913 & .458 & 3.983 & .046 & 2.493 & 1.017 & 6.114 \\
\hline
\end{tabular}

\section{Faktor yang Berpengaruh terhadap}

\section{Kejadian Prediabetes}

Hasil analisis multivariat dapat diketahui bahwa variabel IMT, pola makan, dan merokok secara bersama-sama mempengaruhi kejadian prediabetes. Pada tabel 5 terlihat variabel yang paling berpengaruh terhadap kejadian prediabetes di Puskesmas Pati II adalah IMT dengan nilai odds ratio $(\mathrm{OR})$ atau $\operatorname{Exp}(\mathrm{B})=3,591$.

Hal ini berarti bahwa responden dengan IMT lebih (kegemukan) akan beresiko terjadi prediabetes sebesar 3,591 kali lebih besar dibandingkan responden dengan IMT normal. Oleh karena itu, untuk pencegahan agar terhindar prediabetes diperlukan usaha antisipasi dan treatment khusus untuk menjaga IMT tetap normal seperti menjaga berat badan.

Variabel pola makan dengan OR sebesar 2,435 memiliki arti responden yang memiliki pola makan tidak sehat akan beresiko prediabetes 2,435 kali lebih besar dibandingkan dengan responden yang memiiki pola makan sehat. Salah satu upaya pencegahan peningkatan kadar gula darah adalah dengan perbaikan pola makan melalui pemilihan makanan yang tepat. Pola makan yang tepat adalah pola makan yang disesuaikan kebutuhan energi 
perseorangan. ${ }^{(7)}$ Dengan mengatur pola makan sehat, proses perubahan prediabetes menjadi Diabetes Melitus tipe 2 dapat diperlambat atau bahkan dapat dicegah. ${ }^{(7)}$ Penderita gangguan kadar gula darah dianjurkan untuk melakukan pola makan sehat. Dengan melakukan pola makan sehat akan menstabilkan berat badan dan meningkatkan sensitivitas insulin dan toleransi glukosa, sehingga terhindar prediabetes. $^{(23)}$

Variabel merokok memiliki OR 2,493 berarti bahwa responden yang merokok atau perokok pasif lebih beresiko prediabetes 2,493 kali lebih besar dibandingkan dengan responden yang tidak merokok. Pada studi selama 15 tahun, Coronary Artery Risk Development memperlihatkan bahwa insiden intoleransi glukosa tertinggi terjadi pada current smokers (21,8\%), disusul oleh bukan perokok tapi terpajan secara pasif $(17,2 \%)$, kemudian bekas perokok $(14,4 \%)$, dan yang terendah pada bukan perokok yang tidak terpajan secara pasif $(11,5 \%) .{ }^{(24)}$ Dapat disimpulkan bahwa semakin rendah intensitas terpajan asap rokok, maka semakin rendah resiko terkena intoleransi glukosa yang merupakan tanda awal prediabetes.

Probabilitas IMT, pola makan, dan merokok terhadap kejadian prediabetes pada responden di wilayah kerja Puskesmas Pati II adalah sebesar 56,2\%.
Hal ini berarti bahwa individu yang memiliki kelebihan IMT, memiliki pola makan tidak sehat, dan perokok maka akan memiliki probabiltas untuk terkena prediabetes sebesar 56,2\%.

\section{SIMPULAN}

Angka prediabetes dari penelitian ini sebesar 39,3\%, prosentase terbanyak pada responden dengan Gula Darah postprandial Terganggu (GDPT). Mengingat resiko terhadap kejadian diabetes, maka kelompok yang perlu mendapatkan penanganan cepat adalah responden dengan Toleransi Gula darah Terganggu (TGT) sebesar $10,3 \%$ dan responden yang secara bersamaan GDPT dan TGT.

Penanganan yang tepat untuk prediabetes adalah memberikan arahan perubahan perilaku yang berpengaruh, seperti yang telah dibuktikan pada penelitian ini, yaitu menjaga Indeks Masa Tubuh tidak berlebihan, menjaga pola makan sehat, serta tidak menghisap dan menghirup asap rokok.

$$
\text { Prediabetes hadir sebagai }
$$
peringatan akan fase diabetes mellitus. Hanya saja, karena tidak ada gejala dan keluhan yang khas, sehingga banyak orang yang tidak menyadari keadaan tersebut pada tubuh mereka. Melihat prediabetes dapat kembali menjadi normal, maka diperlukan suatu upaya promosi kesehatan 
untuk menambah kewaspadaan masyarakat terhadap prediabetes. Kegiatan seperti penyuluhan dan sosialisasi yang dikemas dengan pemeriksaan gula darah bisa menjadi salah satu sarana untuk meningkatkan kesadaran terhadap pencegahan diabetes mellitus.

\section{KEPUSTAKAAN}

1. Ekowati, R. Hasil Penelitian PTM Di Depok. Badan Litbangkes Jakarta. 2002.

2. Badan Penelitian dan Pengembangan Kesehatan, Riset Kesehatan Dasar (Riskesdas 2013). Kementerian Kesehatan Republik Indonesia. Jakarta. 2013.

3. Dinkes Kabupaten Pati. Profil Dinkes Kabupaten Pati. Pati: Dinkes Kabupaten Pati. 2016.

4. Centers for Disease Control and Prevention. National Diabetes Statistics Report: Estimates of Diabetes and Its Burden In The United States, 2014. Atlanta, GA: U.S. Department of Health and Human Services, Centers for Disease Control and Prevention. 2014.

5. Soewondo, Perdana dan Pramono, Laurentius. Prevalence, Characteristics, and Predictors of Prediabetes in Indonesia. Department of Internal Medicine, Faculty of Medicine, Universitas Indonesia,
Jakarta. Indonesia Journal of Med J 2011; Vol. 20, (4):283-294.

6. Ellyza, Nasrul \& Sofitri. Hiperurisemia Pada Pradiabetes. 2012. Diakses dalam Jurnal Andalas ISSN: 2301-7406 vol 1 no 2 di akses di http:jurnal.fk.unand.ac.id tgl 15 Januari 2016

7. Heikes, K.E et al. Diabetes Risk Calculator a Simple tool for Detecting undiagnosed Diabetes and Pre Diabetes. Diabetes Care. 2008. Volume 31, Number 5, May 2008 Capter 10401045

8. Direktorat Pengendalian Penyakit Tidak Menular, Ditjen PP \& PL. Petunjuk Teknis Pengukuran Faktor Resiko Diabetes Melitus. Departemen Kesehatan RI. Jakarta. 2008.

9. Nathan David M., MD, Davidson Mayer B., MD, DeFronzo Ralph A., MD. Impaired Fasting Glucose and Impaired Glucose Tolerance Implications for care. American Diabetes Association; Diabates Care: 2007.

10. Trisnawati, Shara \& Setyorogo, Soedijono. Faktor Resiko Kejadian Diabetes Melitus Tipe 2 di Puskesmas Cengkareng II Jawa Barat. Jurnal Ilmiah Kesehatan. 2012 : 5(1)

11. Aulia, Lina Ulfa. Hubungan Antara Kadar Gula Darah Puasa dan FaktorFaktor Risiko Pada Pasien Diabetes 
Mellitus Rawat Inap di RSUD dr. Soebandi Jember. Program Studi Pendidikan Kedokteran. Universitas Jember. 2005.

12. Nezhad et al. Prevalence of Type 2 Type Diabetes Mellitus in Iran and Its Relationship with Gender, Urbanisation, Education, Marital Status, and Occupation. Singapore Med J. 2008.

13. Duke SA. Individual Patient Education for People with Type 2 Diabetes Mellitus. Diabetes Unit, Australian Health Policy Institute, School of Public Health, University of Sydney, Sydney, Australia.2009

14. Abidah Nur, Veny Wilya, Raisuli Ramadhan. Kebiasaan Aktivitas Fisik Pasien Diabetes Mellitus Terhadap Kadar Gula Darah di Rumah Sakit Umum dr. Fauziah Bireuen Aceh. Loka Litbang Biomedis Aceh. 2014

15. Kholila, Nadia. Hubungan Pengetahuan Terkait Diabetes, Aktivitas Fisik, Konsumsi Pangan Sumber Gula dengan Glukosa Darah pada Pekerja Garmen Wanita. Departemen Gizi Masyarakat Fakultas Ekologi Manusia Institut Pertanian Bogor. 2015

16. Kementerian Kesehatan RI. Lampiran Peraturan Menteri Kesehatan Republik Indonesia Nomor 75 Tahun 2013 Tentang Angka Kecukupan Gizi Yang
Dianjurkan Bagi Bangsa Indonesia. Jakarta. 2013

17. Fibriana, Dian. Hubungan Pola Makan Dengan Kadar Gula Darah Pada Penderita Deabetes Melitus. Thesis. FKM Universitas Diponegoro Semarang. 2005

18. Indriyani, P; Supriyatno, H; Santoso, A. Pengaruh Latihan Fisik; Senam Aerobik Terhadap Penurunan Kadar Gula Darah pada Penderita DM Tipe 2 di Wilayah Puskesmas Bukateja Purbalingga. Media Ners. 2007. 1: 4999

19. WHO. Phsical Activity. In Guide Community Service. 2010

20. Fajrinayanti, Ayubi Dian. Faktor Risiko Perilaku Pra-Diabetes di Kota Padang Panjang. Jurnal Kesehatan Masyarakat Nasional. Oktober 2008 : Vol. 3, No. 2

21. Deutrich M, Block G, Norkus EP, Hudes M, Traber MG, Cross CE, Packer L. Smoking And Exposure To Environmental Tobacco Smoke Decrease Some Plasma Antioxidants And Increase Gamma-Tocopherol in Vivo After Adjustment For Dietary Antioxidant Intakes. The American Journal of Clinical Nutrition. 2003

22. Houston, Thomas K; Kiefe, Catarina I; Person, Sharina D; Pletcher Mark; Liu Kiang, and Iribarren, Carlos. Active and Passive Smoking and Development 
Faktor Perilaku dan Gaya... (Ninik T. S., Zahroh S., Antono S.)

of Glucose Intolerance among Young Adults in A Prospective Cohort: Cardia Study. University of California San Fransisco. BMJ Journal. 2006 May 6
23. Jeon, Young Ja. Prevalence of Diabetes and Prediabetes According to Fasting Plasma Glukose and Hbalc. Diabetes and Metabolism Journal. Korea. 2013 Oct; 37(5): 349-357 